いる以上媣刻である。八ローゲン化合物の麻酔剤や笑 気ガス等の麻酔剤が直接, 肝臓や骨髓など生体に砒影 響を与をるばかりでなく高エネルギを放出させる (Energy releasing device) 機器, (電気メス, 紫 外線, レーザメス等) により $\mathrm{N}_{2} \mathrm{O}$ は空素酸化物 $(\mathrm{NOx})$ になり，八ローセンからはBr， $\mathrm{Cl} ， \mathrm{~F}$ が放出され閒接 的に生体に影響をもたらしている。ところが，手術室 のみの環境を考え大気中に麻酔ガスを直接放出する従 来の方法は 2 次公害の原因となる。それらを解決する ため我々は以下の構成からなる装置を開発した. (1)余 剩麻醉ガス排出回路，(ブロアーによる強制排気，バン チュリー回路, 独立した安全回路) (2)八ロゲン化合物 の吸収, 回収装置（活性炭による吸着, 超低温による冷 却回收装置) (3)笑気ガス分解装置 (酸化触媒による分 解， $\left.\mathrm{N}_{2} \mathrm{O} \rightarrow \mathrm{N}_{2}+1 / 2 \mathrm{O}_{2}\right)$ からなりたっている.これら の設置により手術室の環境流如何に改善されたか $\mathrm{N}_{2} \mathrm{O}$, Halothane 濃度の変化からみて考察を加えた。

\section{5. 蘇生訓練教育用患者シミュレータの開発}

東女医大 医用工学

㐘地 真 桜井靖久 東女医大 理論外科

谷下一夫

高研

秋山太一郎

マルコム

原田学

\section{1. 研究目的}

救急蘇生術のように一刻を争う医療技術の習得にあ たっては，実地修練の前に，シミュレータなどによっ て十分な基碟的練習を積み重祆ておくことが望まし い. 特に実地技術の習得は単なるソフトウェアだけの 問題ではないので，きわめてリアルなシミュレータに よって訓練する必要がある。演者らは一昨年の本学会 大会に㧍いて医学教育用患者ロボット開発の重要性を 唱えてシステムの基本的構想を報告したが，試作シミ ニレータがほぼ完成したので報告する.

\section{2. 患者シミュレータの概要}

本シミュレータは, 入力 (各種の治療行為) $\rightarrow$ 情報 処理 (マイクロコンピュータによる判断処理) $\rightarrow$ 出力 （治療による効果, 生体反応, 状態変化）の 3 要素で 構成される. 修練生はまずシミュレータの初期状態 （呼吸・循環・瞳孔などの状態）を観察して診断し， 適切な処習 (気道確保, 人工呼吸, 心臓マッサージ, 必要ならば薬剤注入) をシミュレータに対して施行す
る。この入力が電気信号に変換された後, スコアリン グ回路で評価され有効入力だけがマイクロコンピュー 夕 $(4 \mathrm{~kW})$ 红伝送されて呼吸・循境系諸量を計算す る. その結果に基ゔき脈拍, 血圧, 心尖拍動, 自発呼 吸, 瞳孔縮小などの生体諸反応が患者々同様汇具現さ れる. 本シミュレータ注教育訓練機器であり修練生が 容易に状態変化を把握するように状態表示モニタおよ び教育表示モニタ（施行す心゙き技衍の文字にょる指 令）が具储されている。ささらに口唇の色変化や状態変 化のトレンドカーブを示すカラーディスプレイ装置も 取り付けられ，初期状態の設定や教官からの指示がラ イトペンにより容易に行えるようになっている。

\section{3. 考案}

本シミュレータの特色は閉ループ系により自動的に 生体変化状態を具現する点であり,ソフトウェアの改 变により多様性が生じる。

\section{6. フォトセンサーを用いた麻酔ガス流量} 警報器の試作

北大 手術部
絈 野繁雄 三 浦哲夫
北大 麻酔科
山村剛 康 佐々木和郎

麻酔ガス流量の不意の変化あるいは流量設定の誤認 によって起こる事故を防ぐために，簡便かつ確実なガ ス流量警報装置の開発が望まれているように思われ る.

我々注, フォトセンサーによって麻酔器のロタメー タのボビンの位㚗を検出する麻醉ガス流量警報装置の 開発および塞用化を試みた。

原理 : 酸素および笑気のロタメータのそれぞれ1.5, $5 \mathrm{l} / \mathrm{min}$ の位置に赤外発光ダイオード ( I R- L E D) とフォトトランジスタ（PT) を装着した. ボビンが これらの位置に達した時, あるい通過した時には I R-L E D から P T に達する光量が変化するので， P Tの出力電圧が変化する。これを, シュミットトリガ 一回路で検出し, 単安定マルチバイブレータによって 一定時閒（約 1.5秒）ブザーを駆動するようにした。

特徴：1）麻酔器を使用中, 一定流量より酸素が下 がった場合，あるいは笑気が上がった場合のどちらの 場合でも警報器が作動するので安全度が高い，2）ボ ビンの位置が極めてゆっくり, あるい㴔速に変化し た場合にも確実に動作する，3） ロタメータのボビン の位置を検出しており, 回路の最終段に近い所で流量 変化をチェックしているので信頼性が高い，4）既存 